\title{
The View from HQ
}

\section{Barbara Macikas \\ ACRL Program Assistant}

When I arrived at ACRL in November, 1981, my interim responsibility was to coordinate the first ACRL/NEH workshop on humanities programming for academic librarians. As the workshop was only four weeks away, I was immediately very busy. My first contact with ACRL members was to inform some of them that their applications to the workshop had not been accepted because of the tremendous response we had received and the limited space available.

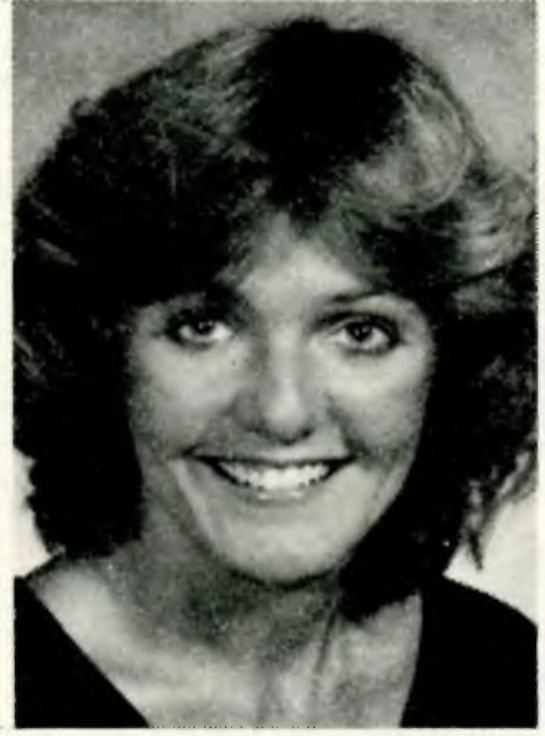

Barbara Macikas Fortunately, everyone was very understanding and we were able to accommodate some of those applicants at our second workshop. Both workshops were well received by those who participated.

After a quite hectic start, things calmed down considerably and I was able to concentrate on my primary responsibility as program assistant to the ACRL continuing education program. I have spent a large amount of time briefing myself on what ACRL has done in the area of continuing education. Currently I spend most of my time on the CE courses which will be offered in Philadelphia. In this column I will discuss those courses, briefly describe how the program works, and consider possible developments within the program of continuing education at ACRL.

Eight continuing education courses will be part of the preconference program at annual conference in Philadelphia. These courses further establish the continuing education program mandated by the ACRL Board of Directors in June, 1979. The development, promotion, and implementation of a long-range continuing education program is my primary responsibility as a program assistant at ACRL.

Four of the eight courses to be offered in Philadelphia, "Librarians as Supervisors," "Strategies and Tactics for Enhancing the Role and Position of the Library within the College or University," "Time Management and Conducting Effective Meetings," and "Survey Research Methods," are newly designed and are offered for the first time by ACRL. The other four courses, "Establishing the College BI Program: The Director's Role," "An Introduction to Maps in Libraries: Maps as Information Tools," "Teaching Methods for the BI Librarian," and "Writing the
Journal Article and Getting It Published," were successfully offered at the ACRL National Conference in Minneapolis last year. The eight courses are 1-2 days long.

Overseeing the courses while they are taught in Philadelphia will be the end of a long series of events which began with the identification of the courses to be developed. Following course identification (and often coincident with it), qualified course designers and instructors from the library and information science community must be identified. If they are interested in design or instruction of a course, are agreeable to the terms of the contract, and are available for the conference dates, then course preparation can begin.

As part of the design contract, course designers provide ACRL with a course syllabus, course objectives, a time schedule and course materials. When the syllabi and materials arrive at ACRL Headquarters, they are carefully reviewed, revised if necessary, and printed. Course promotion then begins and a system of participant registration is implemented. Finally, the courses are offered at conference.

The continuing education program at ACRL is relatively new and still evolving. In addition to an ongoing process of identification and production of courses for conference which address the needs of our members, we are considering new methods of making the courses available. In particular, we are examining ways to offer ACRL-sponsored courses at the local level. Courses could be offered at the local level by ACRL regional groups, library schools, university extension divisions, or interested professional groups. These offerings would provide opportunities for many individuals who cannot schedule courses during conference or who are unable to attend.

The possibility of offering $\mathrm{CE}$ courses at the local level is one development under consideration. Another area being studied is the awarding of Continuing Education Units (CEUs) to course participants. At this time no formal course credit exists for the program. ACRL is exploring the desirability of giving CEUs to course participants.

The ACRL Continuing Education Committee advises on this type of development within the program, and suggests courses which might be successfully implemented. I would like to take this opportunity to invite ACRL members who have suggestions for new courses or who wish to design or teach a course to contact me at ACRL Headquarters.

Developing the continuing education program is now my primary concern at ACRL. However, I am also responsible for special projects which are related to CE. One such project is the ACRL/ NEH Workshops on Humanities Programming for Academic Librarians. In September, 1981, 
ACRL received funding from the National Endowment for the Humanities to conduct two workshops on the subject of humanities programming. These workshops sought to acquaint librarians with the techniques of humanities program development and proposal preparation. I was responsible for the administration of the project. The workshops were held in November, 1981, and February, 1982, in Shrewsbury, Massachusetts, and Los Gatos, California, respectively. Based on experiences at the workshops and participant program evaluations, the workshops were very successful. Because of this success and the great number of applications received, another proposal has been submitted to $\mathrm{NEH}$ for funding of another set of two workshops.

The ACRL/NEH workshops afforded me with an excellent opportunity to meet some of the ACRL membership and I appreciated the cooperation I received from the members who participated. I look forward to the opportunity that the Philadelphia conference will provide to meet more of you.

\section{EXCHANGE LIBRARIANS}

The July/August issue of $C \& R L$ News announced that ACRL would be maintaining a file of American libraries that might be interested in providing the opportunity for a visiting foreign librarian to work on their staff, either in an exchange arrangement, as a temporary replacement, or as a non-salaried visitor. At the same time ACRL asked several foreign library journals to publish this announcement and to ask librarians interested in such an exchange to write to us.

The following institutions have responded to our query. ACRL members interested in an exchange program should write directly to these institutions. Any American libraries willing to participate in an exchange should contact Sandy Whiteley, ACRL/ALA, 50 E. Huron St., Chicago, IL 60611.

H.J. Heaney, University Librarian, Glasgow University Library, Hillhead Street, Glasgow, Scotland G12 8QE.

D.H. Revill, Librarian, Liverpool Polytechnic Library, Walton House, Tithebarn Street, Liverpool, England L2 2NG: "Happy to receive visiting librarians for short periods. Our preference is for librarians from polytechnic-like institutions. We would be interested in placing people in similar institutions-4-year colleges or smaller university libraries."

N.S. Macartney, Deputy County Technical Librarian, Hertis College Library and Information Service, The Hatfield Polytechnic, Hatfield, England AL10 9AD: "Hertis is a county-wide cooperative organization and consists of a large academic library at Hatfield Polytechnic and a number of smaller college libraries."

J.L. Bate, Chief Librarian, Napier College of Commerce and Technology, Colinton Road, Edinburgh, Scotland EH10 5DT: "We are interested in the exchanges you propose, certainly as a non-salaried visitor, and perhaps by a full exchange arrangement."

Michael Breaks, Deputy Librarian, University College Dublin, Belfield, Dublin 4, Ireland: "Our main interest would be in an exchange arrangement but we would judge each inquiry on its merits."

R. Mathys, Vice-Director, Zentralbibliothek Zürich, Zähringerplatz 6, Postfach, 8025 Zürich, Switzerland: "This library functions as a canton, city, and university library. We are interested in discussing possibilities which would allow contacts of this kind with university libraries. As a temporary replacement we think of contracts from 3-6 months; for periods of more than 12 months it is nearly impossible to get work permits."

Jose Orozco Tenorio, Jefe de la Unidad de Documentacion Cientifica, Universidad Nacional Autonoma de Mexico, Escuela Nacional de Estudios Profesionales-Iztacala, Apdo. Postal 314, Tlanepantla, Edo. de Mexico.

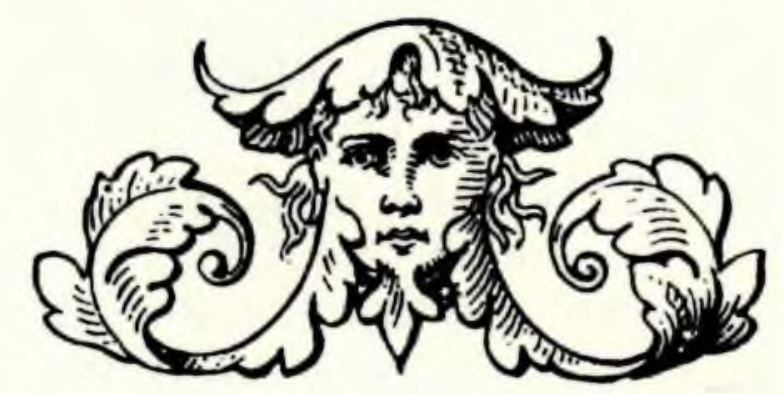

\section{ESPO RESIGNS}

Hal Espo, deputy executive director of ACRL, has resigned his position effective May 7. Espo has been with ACRL for the past four years, in which time ACRL greatly expanded its activities. He worked on ACRL's first national conference in 1978 and had major responsibility for the second national conference last year in Minneapolis. A search for his replacement will begin later in the year.

Meanwhile, Donna Harlan has taken leave from Indiana University at South Bend to fill the

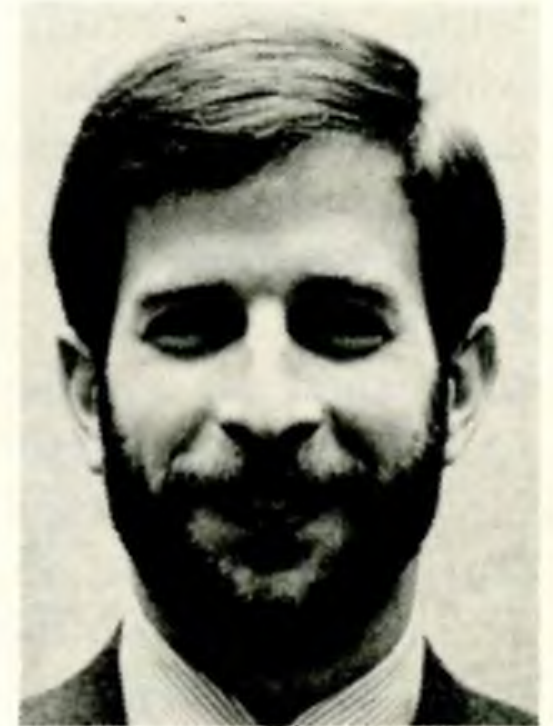

Hal Espo position on an interim basis for one year. Harlan is currently archivist/ reference librarian at South Bend. In 1978 she served as the interim executive director of ALA's Resources and Technical Services Division. She joins ACRL on June 15. 